\title{
Планування програми фізичної терапії для відновлення ходьби після перенесеного інсульту за синергійним типом відновлення
}

\author{
Білянський О. Ю., Скобляк П. І., Рокошевська В. В. \\ Львівський державний університет фізичної культури, м. Львів, Україна
}

\begin{abstract}
Актуальність. За статистикою, третина людей, які щороку переносять мозковий інсульт (MI), - це люди працездатного віку. Можна передбачити, що практично у кожного з пацієнтів та членів його родини буде бажання повернутись до попереднього місця праці. Для цього людині потрібно навчитися долати «наслідки» перенесеного МI. Часто порушення функції ходьби перешкоджає нормальному функціонуванню пацієнта, особливо якщо це відбувається за синергійним типом відновлення.
\end{abstract}

Для досягнення високого рівня функціонування одним із ключових моментів у фізичній терапії $€$ планування реабілітаційного процесу. Увага до згаданої проблеми зумовлена тим, що неточності та помилки при плануванні ставлять під сумнів ефективність усього реабілітаційного процесу, можуть спричинити погіршення стану здоров'я та інвалідизацію пацієнта [1]. Типові програми фізичної терапії орієнтовані на основний клінічний діагноз та період реабілітації, але не враховують супутніх захворювань та ускладнень, типу відновлення та інших індивідуальних особливостей пацієнта. Тому, беручи до уваги різноманітність наслідків після перенесеного мозкового інсульту та неврологічних порушень, вищезазначене питання буде актуальним.

Мета: розробити алгоритм планування програми фізичної терапії для відновлення ходьби після перенесеного інсульту за синергійним типом відновлення.
Опрацьовуючи спеціальну літературу, можна виділити роботу А. Герцика [1], який розділяє планування на 5 функціональних підсистем:

1. Прогнозування; ціль підсистеми - встановити індивідуальну мету фізичної реабілітації/терапії (цільовий рівень рухових функцій).

2. Постановка цілей втручання; ціль - встановити довго- та короткотермінові цілі різної ієрархії.

3. Формування технології втручання; ціль підібрати методи, засоби, форми втручання та іх дозування.

4. Формування технології контролю; ціль підібрати терміни, методи та засоби контролю;

5. Письмове оформлення програми; ціль завершити створення індивідуальної програми [1].

У сучасних підходах до реабілітаційного процесу практично кожний автор у своїх статтях згадує філософію міжнародної класифікації функціонування (МКФ). У МКФ запропоновано повний та загальновизнаний список понять для опису функціонування у суспільстві, незалежно від причин ураження, який має такі складові: діяльність і участь, функції організму, структури тіла, фактори навколишнього середовища. Особи з інвалідністю не належать до окремої категорії. У моделі МКФ наголошено на здоров'ї та функціонуванні, а не на обмеженнях життє- 
діяльності (World health organization, 2002, Geneva) [2].

Класично, плануванню передує обстеження пацієнта, але в реабілітації з неврологічними пацієнтами, враховуючи їхній широкий спектр порушень різних функціональних систем, а особливо різноманітність клінічних інструментів, на це може піти багато часу. Але найбільше розчарування буде, якщо ці тести не визначають тих показників, які необхідні для досягнення кінцевого результату на рівні «участі».

Для планування фізичної терапії ми використовуємо модель МКФ ії поділу на домени, для визначення проблем на кожному рівні, враховуючи запит пацієнта та його рідних.

Рівень 1. «Стан здоров'я». Він передбачає визначення у пацієнта клінічного діагнозу, аналіз історії хвороби та супутніх захворювань.

Рівень 2. «Участь». Яка роль у суспільстві $€$ важливою для нашого пацієнта?

Для того щоб пацієнт був мотивований і програма фізичної терапії була ефективною, він повинен розуміти: для чого він це робить? Як це допоможе йому у повсякденному житті? Якою буде його кінцева мета? Розуміння цього є насамперед важливим для самого пацієнта.

Тому, виходячи з вищесказаного, завдання фізичного терапевта - відшукати максимально реалістичний запит, який є фундаментом подальшого планування.

Ми повинні довідатись: Чим займався пацієнт до травми? Яка його професія? Які в нього захоплення, хобі, інтереси? І запитати: Що найбільше він би хотів зараз робити? Досить часто ми можемо почути речі, які нашим пацієнтам не під силу, тому, враховуючи діагноз та індивідуальність пацієнта, ми повинні спростити бажання пацієнта. В окремих випадках буває, що досягнення певного результату для конкретного пацієнта може бути неможливим, тому слід використати щось інше. Головне - щоб роль пацієнта, яку він хоче відігравати у житті, була реалістичною.

Рівень 3. «Діяльність/Активність». Визначившись 3 пріоритетним завданням на рівні «участі», потрібно дослідити: які обмеження у діяльності спричиняють для цього перешкоди? А також: які навички необхідні для досягнення вищезазначеної ролі? До обмежень на рівні діяльності можуть відноситись: переміщення, їзда на візку, машині, усвідомлення безпеки, самообслуговування, когнітивні здібності; але найактуальнішою $€$ ходьба. Багато речей, які хочуть виконувати пацієнти, вимагають від них самостійного переміщення.

Рівень 4. «Структури та функції тіла». Структури організму - це частини нашого тіла, наприклад: органи, кінцівки, м'язи, кістки тощо. Всі вони у взаємодії чи кожен окремо виконують свої функції, які забезпечують нормальне функціонування організму. Головним завданням для фізичного терапевта $є$ визначення порушень, які обмежують виконання повсякденної діяльності. Обмеження можуть бути різними: це амплітуда руху, спастика/тонус, сила, соматосенсорика, планування руху, рівновага, швидкість та витривалість.

Складається логічний ланцюг дій, який дозволяє мислити фізичному терапевту від загального до конкретного. Знаючи головну мету, потрібно визначити, яку активність слід виконувати пацієнту i, зрештою, щоб підтвердити гіпотезу, необхідно дослідити головну причину на рівні тіла, яка не дозволяє виконати конкретну дію. Але для того, щоб побачити картину в цілому, слід врахувати ще два дуже важливих рівні.

Рівень 5. «Особистісні фактори». Із назви стає очевидним, що сюди відноситься все те, що стосується внутрішнього світу нашого пацієнта. В ході розмови виявляється мотивація пацієнта, його зацікавленість у фізичній терапії, духовність, враховуємо стать і вік.

Рівень 6. «Фактори середовища». Їх можна розділити на позитивні і негативні. Позитивні - це всі ті фактори навколишнього середовища, які допомагають людині на різних рівнях функціонування. Сюди відноситься: підтримка сім'ї, палиця, поруччя в будинку біля сходів, різноманітні підказки тощо. До негативних факторів, які обмежують якість життя, відносяться: архітектурні перешкоди, неякісне обладнання, відсутність підтримки та інші.

Ці два домени $є$ важливими для планування програми фізичної терапії, i їх слід довідуватись у контексті розмови.

Після структуризації проблем на кожному з рівнів та маючи довгострокову мету, на 
рівні «участі» відбувається постановка короткострокових цілей у «SMART»-форматі на рівні структури та діяльності. Згідно з даним підходом, цілі повинні бути:

- Specific - конкретні;

- Measurable - вимірні;

- Attainable, achievable - досяжні, здійсненні;

- Relevant - відповідні;

- Time-bound - визначені у часі [4].

Наступним кроком є підбір науково обгрунтованих клінічних інструментів для вимірювання показників, які потрібні для досягнення цілей. Існує велика кількість текстів для оцінки функції ходьби: 10-хвилинний тест ходьби, 6-хв. тест, 4 квадрати, “Timed Up and Go”. Моторний контроль вертикалізації, динамічний індекс ходи, спостережний аналіз ходи, шкала балансу Берга та інші [5].

Маючи такий великий об'єм потрібної та структурованої інформації, можна виконати головне завдання планування - створення програми фізичної терапії.

Висновок. Перевагою структурного збору інформації є те, що, відштовхуючись від запиту пацієнта, можна визначити конкретні проблеми на різних рівнях, які обмежують головне бажання пацієнта. Відшукуючи проблеми від «участі» до «структури», ця модель змушує рухатись від загального до конкретного.

\section{Література:}

1. Герцик А. Створення програм фізичної реабілітації/терапії при порушеннях діяльності опорно-рухового апарату / Андрій Герцик // Слобожанський науково-спортивний вісник. - Харків : ХДАФК, 2016. № 6(56). - С. 37-45. - doi: 10.15391/ snsv.2016-6.006

2. Международная классификация функционирования, ограничений жизнедеятельности и здоровья: МКФ: краткая версия. URL: apps.who.int/iris/bitstre am/10665/85930/1/9241545445_rus. pdf?ua $=1$

3. Рокошевська В., Крук Б. Застосування моделі міжнародної класифікації функціонування (мкф) у фізичній терапії осіб після перенесеного мозкового інсульту / Віра Рокошевська, Богдан Крук // сучасні тенденції у практиці і освіті фізичної терапії. - Львів: УДК 615.825:616.831005.1

4. Hertsyk A. SMART goal setting in physical therapy / A. Hertsyk // Фізичне виховання, спорт і культура здоров'я у сучасному суспільстві: зб. наук. пр. Східноєвроп. нац. ун-ту ім. Лесі Українки. - Луцьк : Східноєвроп. нац. ун-т ім. Лесі Українки, 2016. - № 2 (34). -C. 57-63.

5. www.sralab.org/rehabilitation-measures 